\title{
高減衰鋼片の超音波探傷技術
}

片岡克仁*

\section{Development of Ultrasonic Inspection Technique for Steel Billets with High Acoustic Attenuation}

\author{
Katsuhito Kataoka
}

\section{Synopsis}

Various nondestructive testing have been applied for steel products in manufacturing processes. Ultrasonic inspection is an important method to evaluate inclusions in rolled billets. Conventional ultrasonic transducer with a flat piezoelectric element is used for the inspection. However, ability of inspection for a part of chromium stainless steel billets with coarse grain is insufficient with comparison to the ability for carbon steel billet. This paper describes a result of development of new ultrasonic transducers for the billets with coarse grain. Numerical analysis with finite element method was carried out to make sure a best frequency and wave shape. Two transducers are designed and confirmed advantages over the conventional transducers.

\section{1. 緒言}

大同特殊鋼(侏)は, スクラップを原料として, 溶解, 鋳造, 各種圧延工程を経て, 大型の角製品, 丸製品から, 平鋼, 棒鋼，線材，帯鋼製品，などを生産している。このよう に, 多岐にわたる鋼製品に対して, 内質検査は重要である. 内質検査が不適切であれば，製品の使用中に損傷や破壊 が起こり，人身事故を伴う重大な災害を招くこともある。

内質検査を最終製品に適用する場合，多種多様な形状 や寸法に即した設備が必要で, 場合によっては, 検査自 体が困難な場合がある。このため, 中間製品にあたる鋼 片での内質検査（超音波探傷）の要求は特に大きい。通 常の鋼片には, 周波数が数 $\mathrm{MHz}$ の超音波を用いて探傷し ている.しかし，一部のフェライト系ステンレス鋼や電 磁ステンレス鋼においては, 結晶粒が $1 \mathrm{~mm}$ 程度と粗大 化しているものもあり (以後, 高減衰鋼片という), 粒界 散乱により微小な欠陥の検出性能が低下することがあり， 改善が望まれていた。

そこで, 今回, 高減衰鋼片の超音波探傷精度の向上を
目指し，(1) 高減衰鋼片の超音波特性を明らかにし，(2) 結晶粒界散乱を考慮した数值解析により探傷条件を最適 化し，(3) 全断面探傷を可能とする技術を開発した。

\section{2. 超音波特性調査}

調査する鋼片として，二種類のフェライト系ステンレ ス鋼 (SUS430, SUS405 modified) と, 比較のため, 減衰 の少ない構造用鋼 $(\mathrm{SCM} 435)$ を用いた。

\section{1 結晶粒径分布}

鋼片断面のマクロ観察を実施し, 結晶粒径分布を測定 した。測定結果を Fig.1に示す。構造用鋼の結晶粒径は, 鋼片断面の表層から中心まで, 直径 $0.05 \mathrm{~mm}$ 以下でほほ 均一であるのに対し，フェライト系ステンレス鋼は，中 心に近づくにつれ，結晶粒径が大きくなっていた。なお， 中心近傍の粒径は, SUS430 では $1.6 \mathrm{~mm}$ 程度, SUS405 modified では $0.8 \mathrm{~mm}$ 程度であった。

\section{2 超音波減衰特性}

鋼片の粗大結晶粒部 (鋼片の中心部近傍) を切り出 


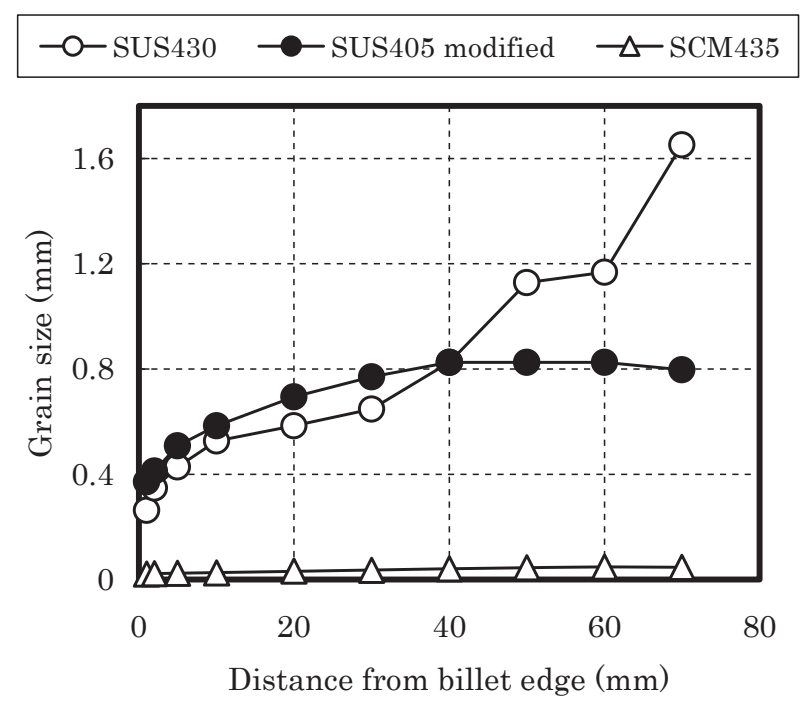

Fig.1. Grain size distribution of the billets.

し，超音波を入射したときの第 1 回目の底面エコーと第 2 回目の底面エコーの比率より, 鋼片の超音波減衰特性 を調査した。調查結果を Fig.2に示す。構造用鋼に比べ, フェライト系ステンレス鋼の減衰は大きく，探傷周波数 $5 \mathrm{MHz}$ においては, 構造用鋼が $0.05 \mathrm{~dB} / \mathrm{mm}$ に対し, フェ ライト系ステンレス鋼は $0.20 \mathrm{~dB} / \mathrm{mm}$ であった。 また，探 傷周波数が，低周波数になるにつれて，超音波減衰が小 さくなることがわかった。この調査より，散乱減衰の著 しいフェライト系ステンレス鋼には, 低周波数が有効で あることがわかった。
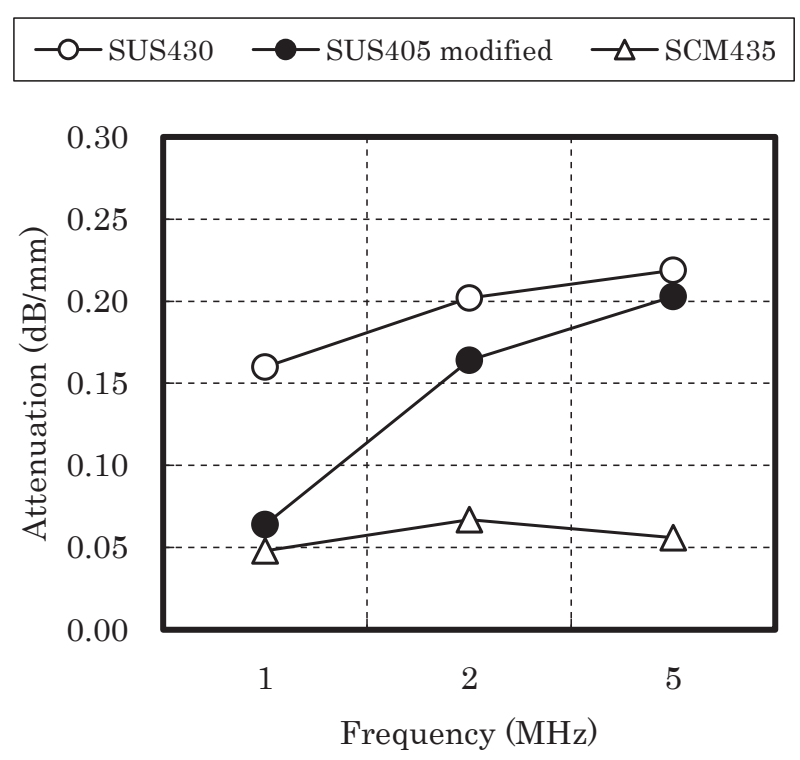

Fig.2. Characteristic of acoustic attenuation.

\section{3. 数値解析による探傷条件の最適化}

\section{1 結晶粒界散乱を考慮した数值解析法}

数值解析には, 有限要素法の陽解法を, 要素分割には, ボロノイ分割法を用いた。陽解法とは，ある時刻 $\mathrm{t} に お ~$ ける值を基にして微少に進んだ時刻 $\mathrm{t}+\Delta \mathrm{t}$ の值を代数 的に求め, それを繰り返し計算していく方法である. $\Delta \mathrm{t}$ だけ時間を進めたときの值を計算するのは，収束計算を 用いない比較的簡単な演算であるため, 1 つの時間ステッ プの演算負荷は低いが， $\Delta \mathrm{t}$ を大きく取りすぎないよう， 非常に多くの時間ステップが必要である. しかし, 最近 のコンピュータ技術の発展により, 高速に計算可能であ る。ボロノイ分割法では, 解析領域内に結晶粒密度に応 じた数の母点をランダムに配置し，それぞれの母点間を 結んだ直線の垂直二等分線を描き，これを結晶粒界とし た ${ }^{1)}$. 次に，粒界散乱波の発生原因を結晶粒間の異方性 主軸方向の違いによる音響インピーダンスの差のみに限 定し，結晶粒ごとに異なる異方性主軸方向を与えること で粒界散乱波を表現した ${ }^{1)}$. 作成した解析モデルを Fig.3 に示すが，実際のフェライト系ステンレス鋼片断面のマ クロ観察写真 Fig.3(a) と類似した解析モデルが得られた。

数值解析条件は, 探傷周波数 $1.0 \sim 3.0 \mathrm{MHz}$, 周波 数帯域は広帯域と狭帯域, 超音波振動子径は $20 \mathrm{~mm}$ と $30 \mathrm{~mm}$, 人工欠陥 (横穴) の深さをパラメータとして, Table 1 の条件で解析した。

Table 1. Condition of numerical analysis.

\begin{tabular}{l|l}
\hline Condition & Value \\
\hline Frequency & $1.0 / 1.5 / 3.0 \mathrm{MHz}$ \\
\hline Frequency bandwidth & Broadband / Narrowband \\
\hline Transducer shape & Flat-faced / Focused \\
\hline Transducer diameter & $20 \mathrm{~mm} / 30 \mathrm{~mm}$ \\
\hline Defect diameter & $1 \mathrm{~mm}(\mathrm{SDH})$ \\
\hline Defect depth & $35 \mathrm{~mm}$ \\
\hline
\end{tabular}

\section{2 数值解析による最適探傷条件}

数值解析例を Fig.4, Fig.5に示す。これらの波形は, 人工欠陥を深さ $35 \mathrm{~mm}$, 直径 $1 \mathrm{~mm}$ の横穴とし, 横軸を 伝播時間, 縦軸をエコー強度として, Fig.4 が広带域（波 数 1.5 波）の場合, Fig. 5 が狭帯域（波数 4 波）の場合で ある. 人工欠陥のエコーは, 伝播時間 $10 \sim 15 \mu \mathrm{s}$ の位 置に現われ，底面 $150 \mathrm{~mm}$ に相当するエコーは $50 \mu \mathrm{s}$ 付 近に現われている.

また，Fig.4に示す広帯域超音波を用いた解析例では， 周波数 $1.0 \mathrm{MHz}$ の場合が, 最も欠陥からの信号が大きく, 高周波になるにつれ，その信号強度が小さくなっている. 


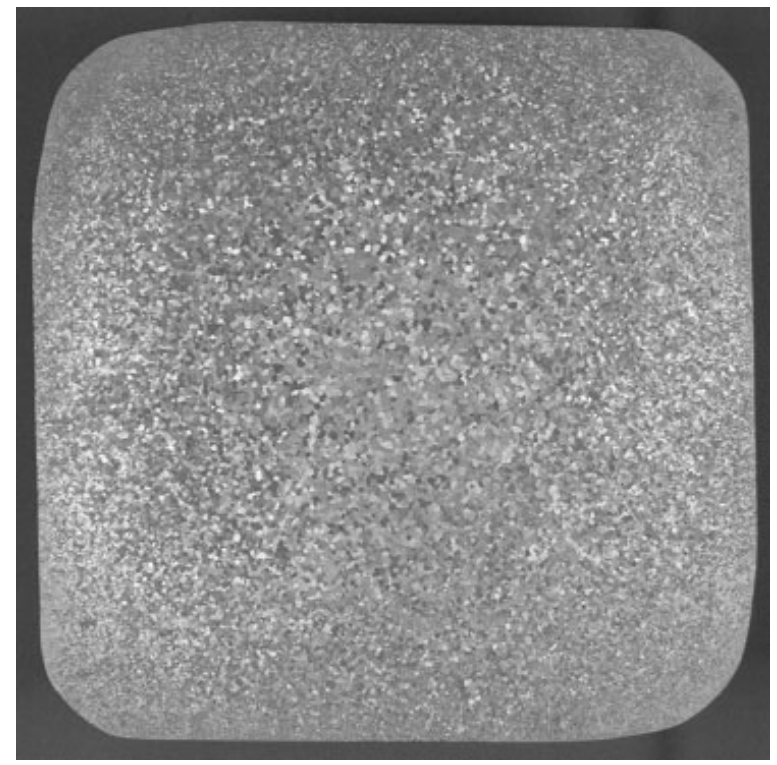

a) A section photograph of a billet

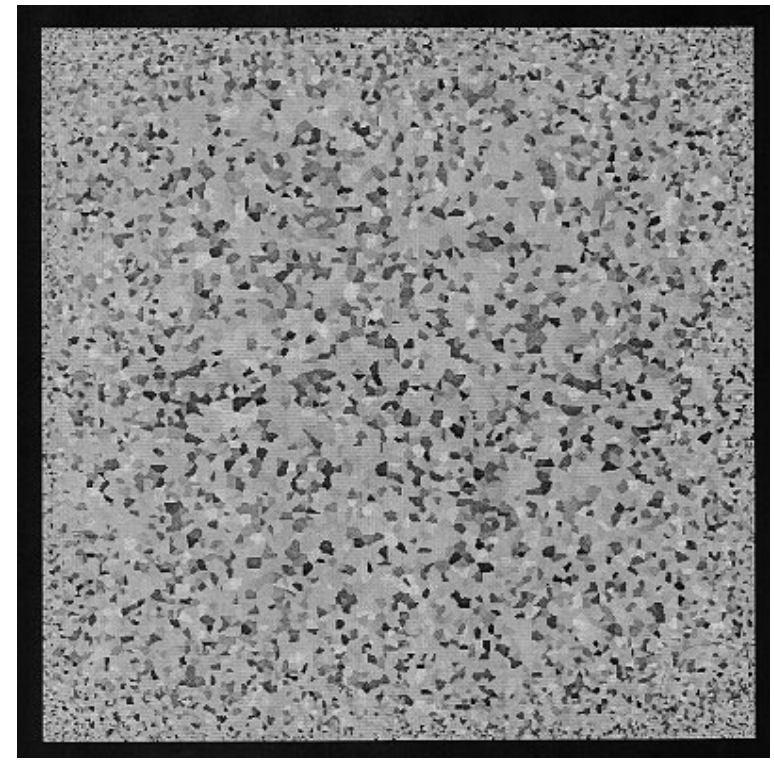

b) A model for the numerical analysis

Fig.3. A section photograph of a billet and a model for the numerical analysis.

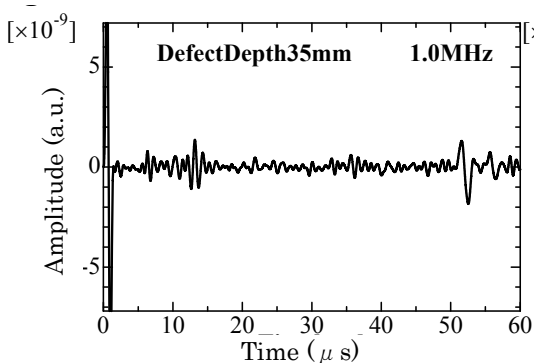

(a) Frequency $1.0 \mathrm{MHz}$

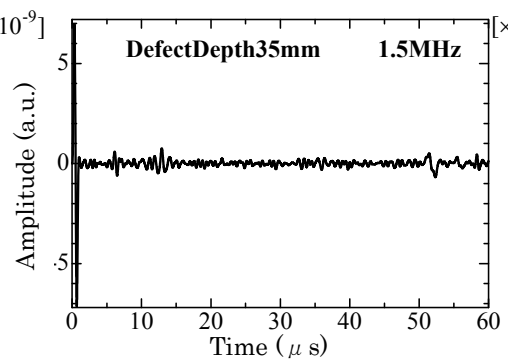

(b) Frequency $1.5 \mathrm{MHz}$

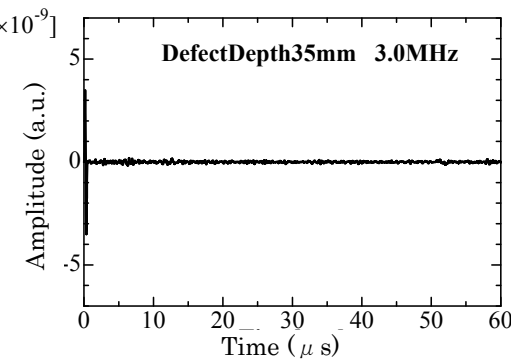

(c) Frequency $3.0 \mathrm{MHz}$

Fig.4. Results of numerical analysis with broadband ultrasound.

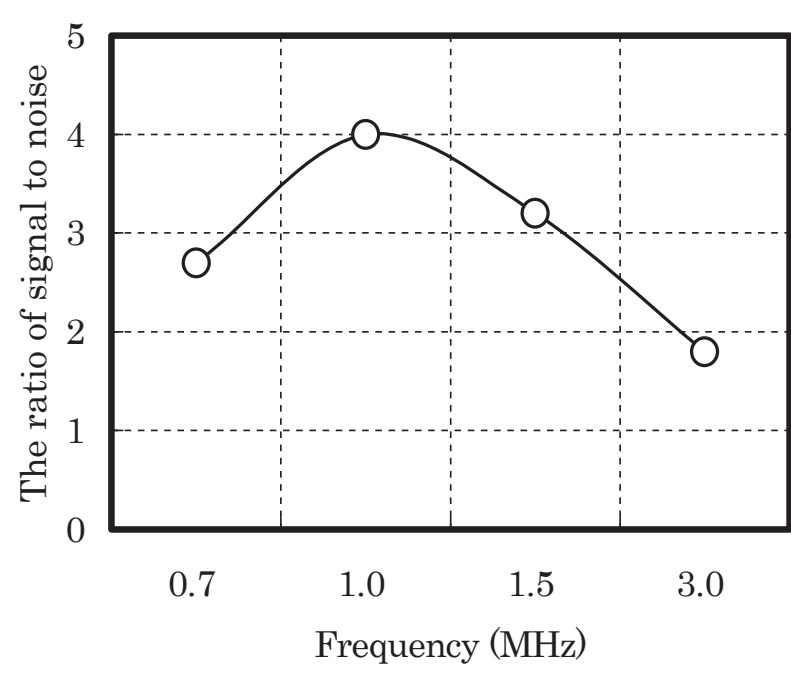

Fig.5. Frequency dependence of $\mathrm{S} / \mathrm{N}$ ratio with broadband ultrasound.

特に，3.0 MHzでは，欠陥エコーが見られない. 周波数 帯域が広帯域の場合の探傷周波数と $\mathrm{S} / \mathrm{N}$ 比の関係を Fig.5 に示す. Fig. 5 より, 周波数 $1.0 \mathrm{MHz}$ の $\mathrm{S} / \mathrm{N}$ 比が最良で あった。 また, 周波数帯域を広帯域から狭帯域にすると,

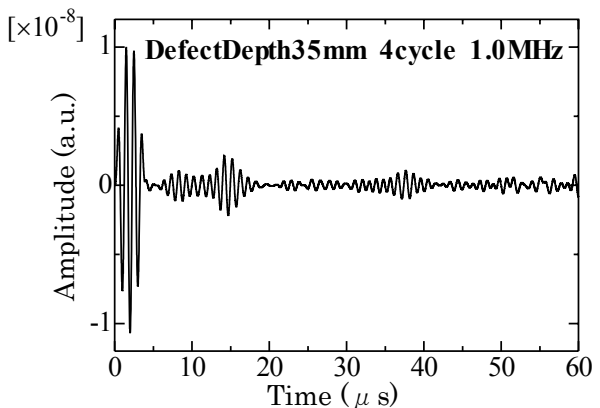

Fig.6. Results of numerical analysis with narrowband ultrasound frequency $1.0 \mathrm{MHz}$.

Fig.6に示すように欠陥エコーは識別できるものの，エ コーの波数が多いため, 欠陥エコーの識別性が悪くなっ ている。これらの結果から，探傷周波数は，1.0 MHzの 場合が最良であり，周波数帯域は広帯域の方が $\mathrm{S} / \mathrm{N}$ 比が 良好であった。

次に，先の解析結果で良好であった周波数 $1.0 \mathrm{MHz}$, 広帯域（波数 1.5 波）に拈いて, 超音波の集束効果と振 動子径について解析した. 数值解析例を Fig.7 に示す. 


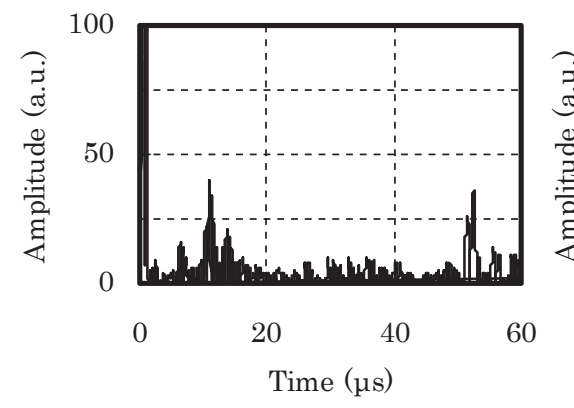

(a) Diameter $20 \mathrm{~mm}$, Flat-faced (Unfocused)

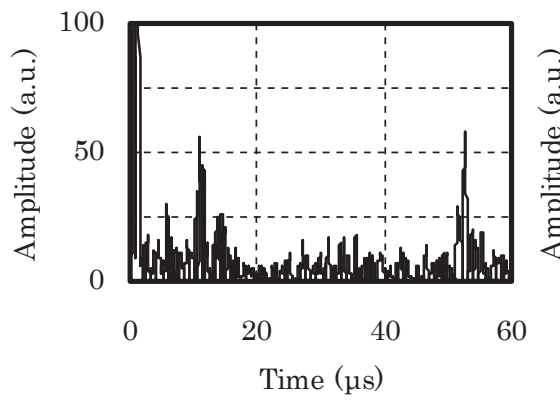

(b) Diameter $20 \mathrm{~mm}$, Cylindrical Focus

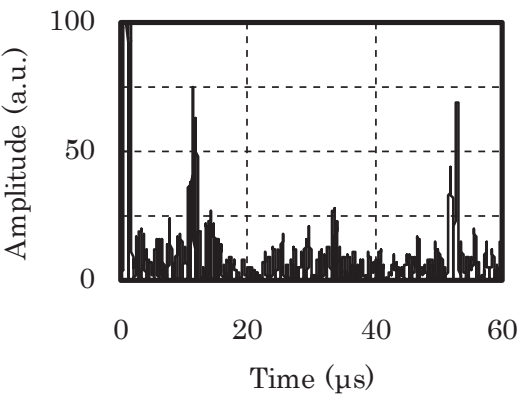

(c) Diameter $30 \mathrm{~mm}$, Cylindrical Focus

Fig.7. Results of numerical analysis with variation in transducer diameter and focal types.

なお，Fig.7では欠陥エコー高さに着目するため，全波整 流波形となっている。同じ振動子径で，超音波集束無し (Fig.7 (a)) と集束あり (Fig.7(b)) の場合では，後者の方が， 欠陥エコーが大きくなっている。 また，同じ超音波集束 ありの場合で，振動子径を大きくする $(\mathrm{Fig} .7(\mathrm{c}))$ と，さら に欠陥エコーが大きくなる。これらの結果より，高減衰 鋼片の超音波探傷において, 超音波の集束と振動子の大 径化が有効であると判断した。

以上の数值解析より, 高減衰鋼片の超音波探傷におい て, 低周波数 (1.0 MHz) で広帯域の超音波を用い, 振動 子径を大きく, かつ, 集束させることが必要であるとの 結果が得られた。

\section{4. 各探触子の開発}

従来法（平面探触子による手探傷）を比較対象として, 数值解析に基づくフォーカス法（点集束探触子）の適用 を検討した。

\section{1 点集束探触子の開発}

数值解析の最適条件に従い, Table 2 に示す点集束探触 子を開発した。

探触子の性能調査には, Fig.8に示すような深さの異な る直径 $1 \mathrm{~mm}$ の横穴を加工した鋼片を用いた。また、性 能比較のために, 周波数 $1 \mathrm{MHz}$, 振動子径 $20 \mathrm{~mm}$ の平面 振動子の従来探触子でも調査した。

Fig.9 に今回，開発した点集束探触子を，Fig.10に従来 探触子を用いた場合の深さの異なる横穴からの反射波形

Table 2. Specification of spherical focus transducer.

\begin{tabular}{l|l}
\hline Condition & Value \\
\hline Frequency & $1.0 \mathrm{MHz}$ \\
\hline Frequency bandwidth & Broadband \\
\hline Transducer shape & Spherical surface \\
\hline Transducer diameter & $40 \mathrm{~mm}$ \\
\hline Focal types & Point focus \\
\hline Focal depth & $80 \mathrm{~mm}$ \\
\hline
\end{tabular}

を示す，探傷感度は，それぞれノイズエコーが同程度に なるように調整した。 これらの波形を見ると，欠陥深さ $45 \mathrm{~mm}$ では，それぞれ同程度のエコー強度であるが，欠 陷深さ $80 \mathrm{~mm}$ 以上では, 点集束探触子のエコー強度が, 従来探触子を上回っているのがわかる.

次に，先の探傷波形より，陥エコー強度をシグナル (S) とし, 送信エコーと欠陥エコーと底面エコーを除外し た波形のピークをノイズ $(\mathrm{N})$ として $\mathrm{S} / \mathrm{N}$ 比を求め, グラ フにまとめたものを Fig.11 に示す。横軸が久陥深さ, 縦 軸が S/N 比である，Fig.11より，従来探触子では，欠陥 深さに反比例して $\mathrm{S} / \mathrm{N}$ 比が悪くなるのに対し，点集束探 触子は浅いところで従来を下回るものの，深いところで は従来を上回る良好な $\mathrm{S} / \mathrm{N}$ 比になった。

以上の結果から，今回開発した点集束探触子は，深さ $50 \mathrm{~mm}$ 以上の鋼片内部の探傷性能は従来を上回ること, 表層部 $20 \mathrm{~mm}$ 以内では感度が低下することがわかった。

\section{2 分割型探触子の開発}

前述の点集束探触子の課題である表層部を探傷するた めに，送信エコーによる表層不感帯の影響を受けない二 探触子法（分割型探触子）の適用を検討した。二探触子 法は，二個の超音波振動子を用いて，超音波の送信と受 信を別々に行うものである

開発した分割型探触子の仕様を Table 3 に示す。周波 数は, 表層部の結晶粒径が内質部に比べ細かいため, 高 周波数 (2 MHz) を選定した。また，送受信ビームの交軸 範囲を表層直下から $30 \mathrm{~mm}$ 程度になるように振動子傾斜

Table 3. Specification of dual element transducer.

\begin{tabular}{l|l}
\hline Condition & Value \\
\hline Frequency & $2.0 \mathrm{MHz}$ \\
\hline Transducer shape & Concave radius \\
\hline Transducer type & Dual element transducers \\
\hline Element size & $10 \times 15 \mathrm{~mm}$ \\
\hline Roof angle & $7.2 \mathrm{deg}$. \\
\hline
\end{tabular}




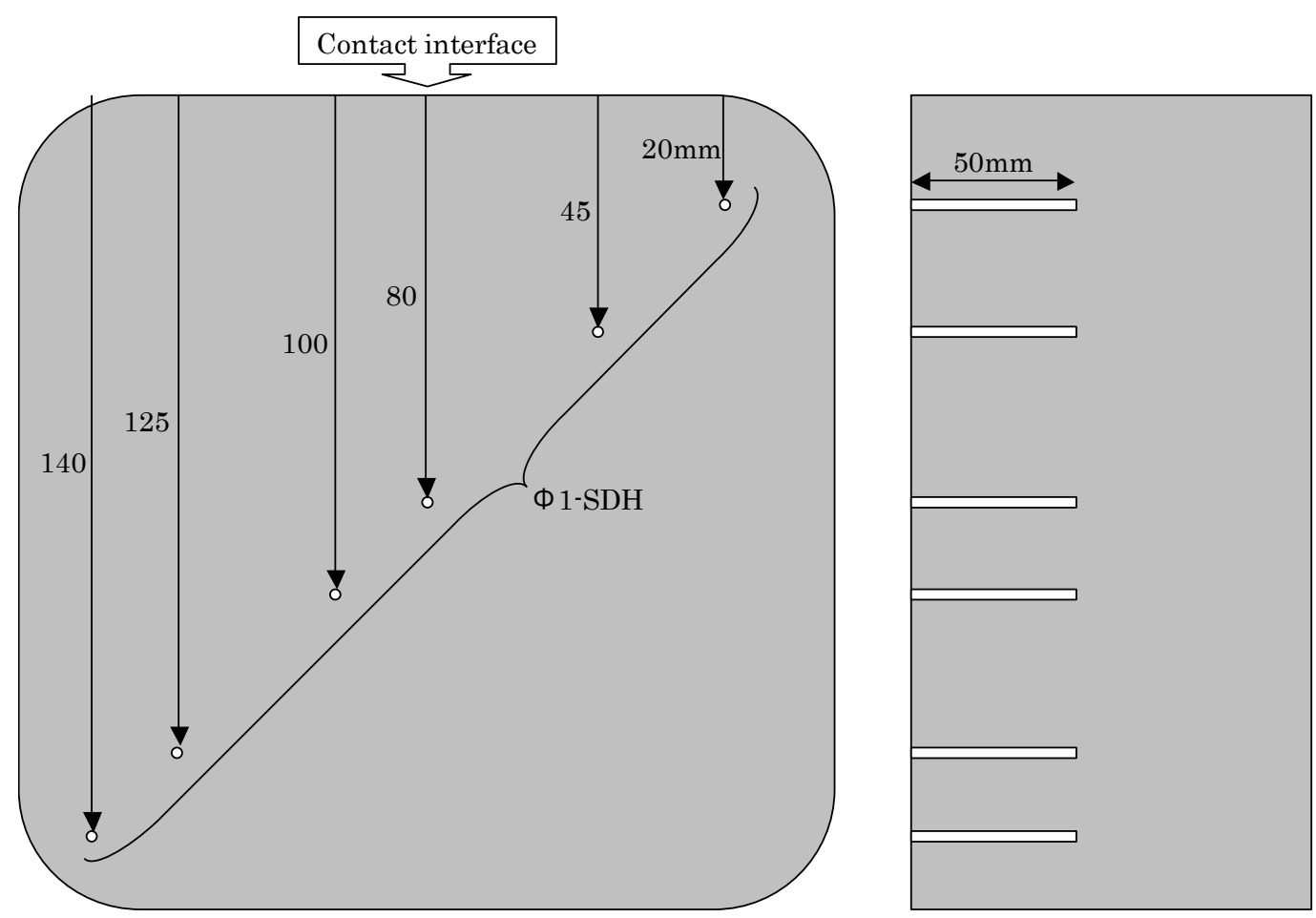

SDH:Side Drill $\underline{H}$ ole

Fig.8. Defect layout of the steel billet sample.

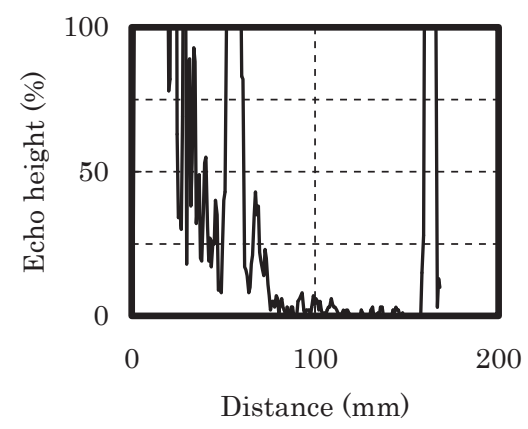

(a) Defect depth $45 \mathrm{~mm}$

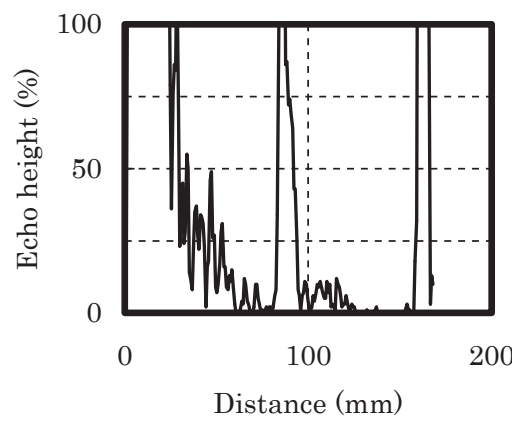

(b) Defect depth $80 \mathrm{~mm}$

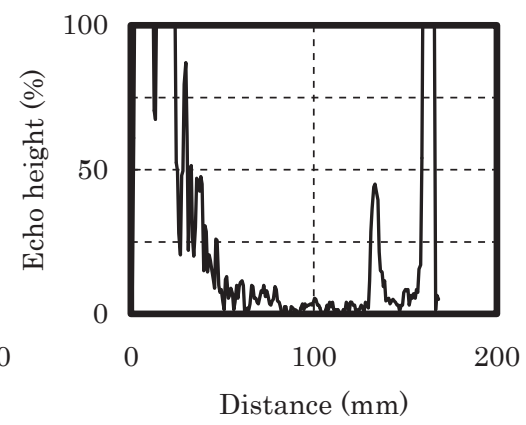

(c) Defect depth $125 \mathrm{~mm}$

Fig.9. Results of ultrasonic testing with the spherical focus transducer.

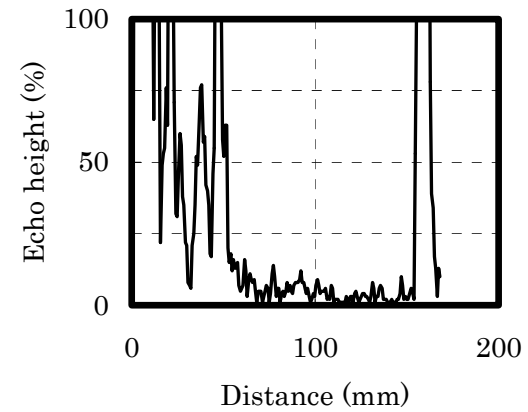

(a) Defect depth $45 \mathrm{~mm}$

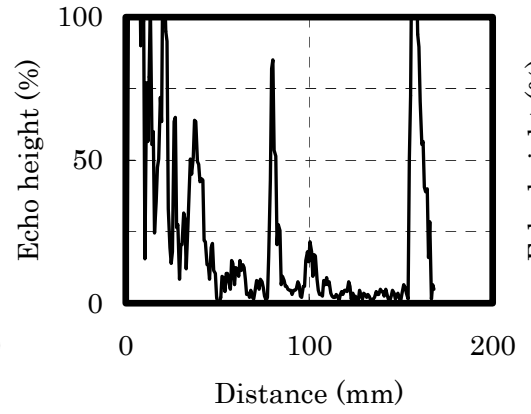

(b) Defect depth $80 \mathrm{~mm}$

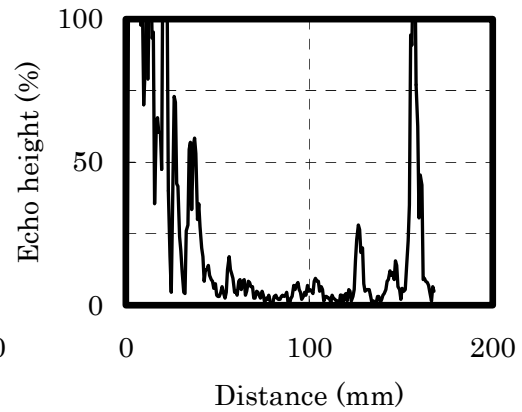

(c) Defect depth $125 \mathrm{~mm}$

Fig.10. Results of ultrasonic testing with a conventional transducer. 


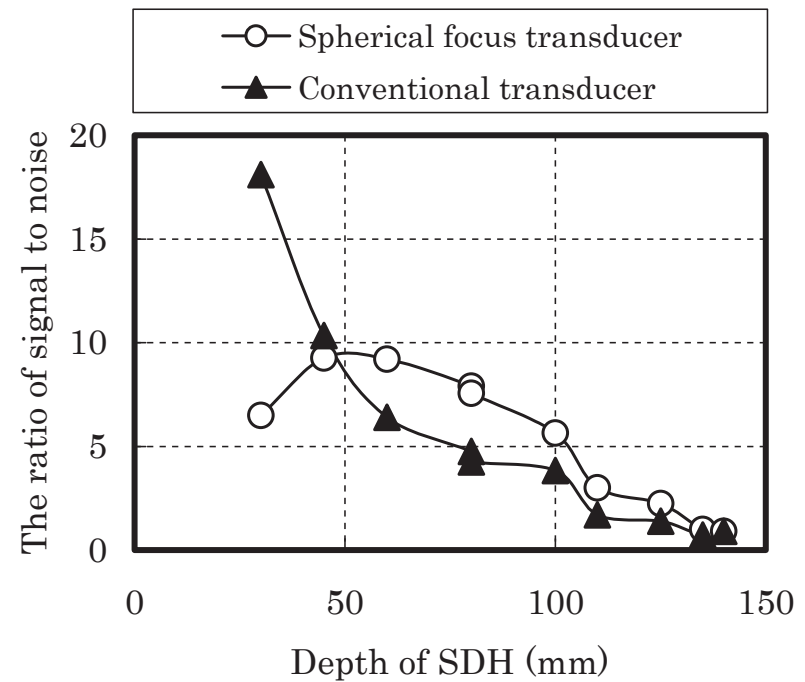

Fig.11. Comparison of $\mathrm{S} / \mathrm{N}$ ratio between spherical focus transducer and conventional transducer.

角を設け，振動子を曲面状とし，交軸点でビームの集束 性を高めた。

分割型探触子の性能調查には, Fig.12に示すようなア ルミ試験片を用いた。調査結果を Fig.13に示すが，欠陥 深さ $2 \mathrm{~mm}$ 以上では，きずからのエコーの立上りが明瞭 であるが，欠陷深さ $1 \mathrm{~mm}$ では，健全部と波形形状に若 干の差異がわかるだけである。次に，これらの探傷波形 から S/N 比を求め, グラフにまとめたものを Fig.14 に示 す. Fig.14より, 久陷深さ $1 \mathrm{~mm}$ では, S/N 比が 2 未満で

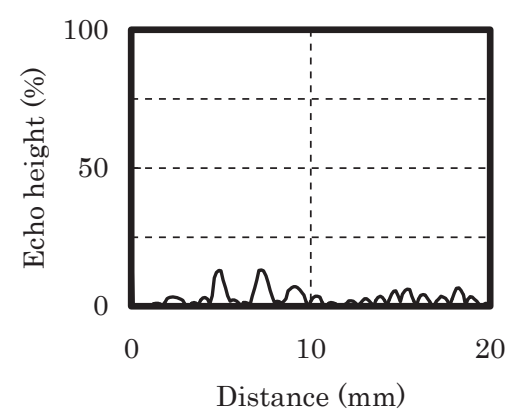

(a)Non-defect aera

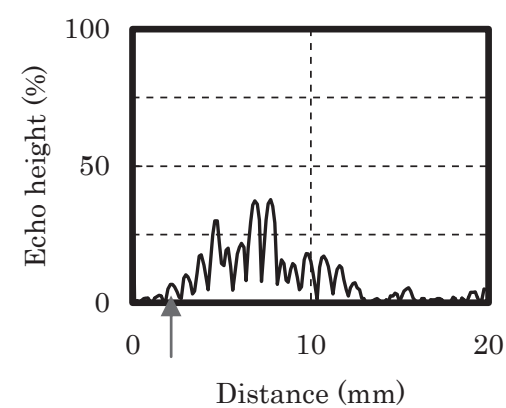

(c) Defect depth $2 \mathrm{~mm}$

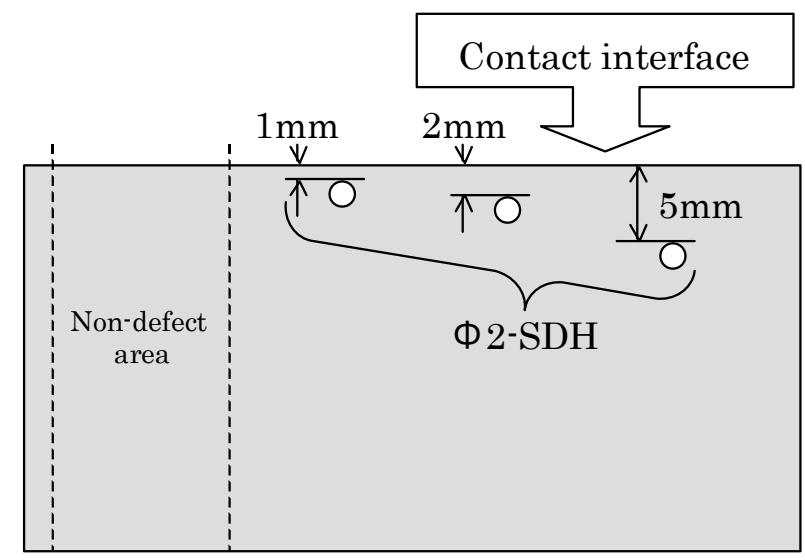

Fig.12. Defect layout of the aluminum billet sample.

欠陥判別は難しいが， 欠陥深さ $2 \mathrm{~mm}$ 以上では $\mathrm{S} / \mathrm{N}$ 比が 8 以上であり，欠陥判別は可能である。

以上の結果から, 分割型探触子は, 表層直下 $2 \mathrm{~mm}$ 以 上の欠陥が検出可能である。

\section{5. 結 論}

分塊圧延された鋼片には, 結晶粒が粗大で, 超音波探 傷が困難な高減衰鋼片がある。今回, この高減衰鋼片の 超音波探傷条件を, 数值解析を用いて検討し, 探触子を 開発した結果, 以下の結論が得られた。

(1) 粗大結晶粒を持つ高減衰鋼片の超音波減衰は, 構造用 鋼に比べ著しく大きく, $0.20 \mathrm{~dB} / \mathrm{mm}$ であった。

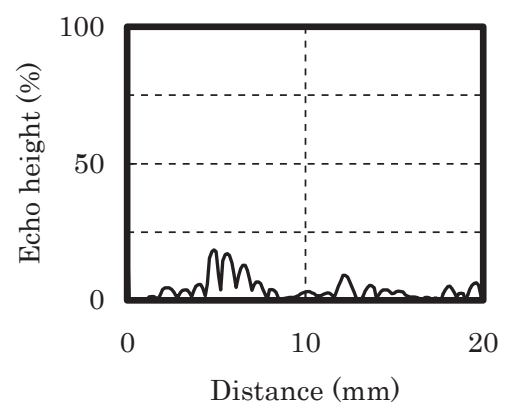

(b) Defect depth $1 \mathrm{~mm}$

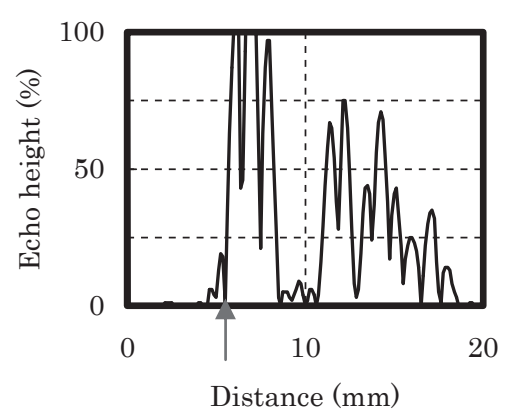

(d) Defect depth $5 \mathrm{~mm}$

Fig.13. Results of ultrasonic testing with the dual element transducer. 


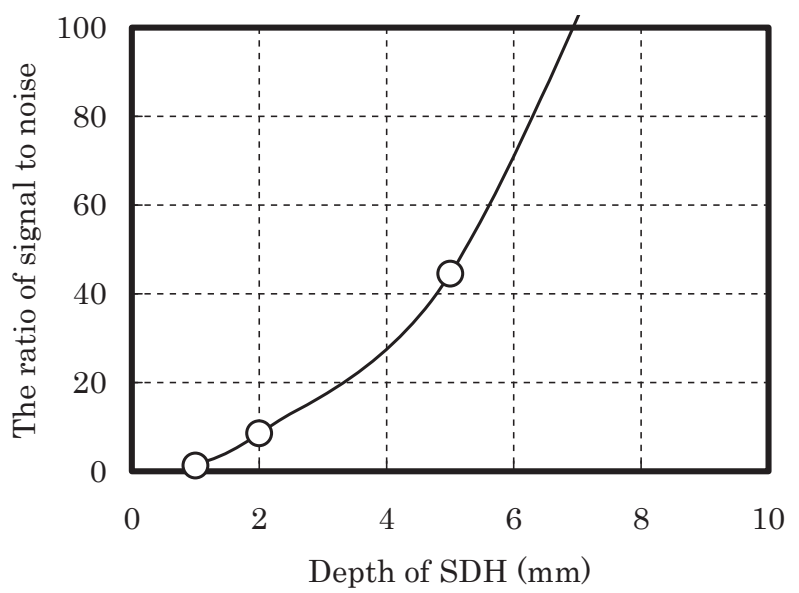

Fig.14. Depth dependence of $\mathrm{S} / \mathrm{N}$ ratio of the dual element transducer.

(2) 結晶粒界散乱を考慮した数值解析より, 高減衰鋼片の 超音波探傷には, 低周波数 $(1.0 \mathrm{MHz})$ で広帯域の超音波 を用い，振動子径の大きい点集束探触子が最適である。

(3) 開発した点集束探触子において, 深さ $50 \mathrm{~mm}$ 以上で 従来探触子に比べ $\mathrm{S} / \mathrm{N}$ 比が 2 〜向上することができた. (4) 表層部用に開発した分割型探触子において, 深さ 2 $10 \mathrm{~mm}$ において，S/N 比 8 以上が得られた。

なお，開発した探触子は，改良を加え，製品検査に適 用中である。また，さらに，高減衰鋼片の全長，全断面 探傷の自動化に，アレイ超音波探傷法の適用を検討中で ある。

最後に，本技術開発を遂行するに当たり，多大な協力 をしていただきました名古屋工業大学 伊藤智啓准教授 に謝意を表します。

\section{(文 献)}

1）中村正也, 伊藤智啓：第 12 回超音波による非破壊シ ンポジウム, 2005, 15 